Cornell University Law School Scholarship@Cornell Law: A Digital Repository

$11-2018$

\title{
Trade and Development in an Era of Multipolarity and Reterritorialization
}

Chantal Thomas

Cornell Law School, chantal-thomas@lawschool.cornell.edu

Follow this and additional works at: https://scholarship.law.cornell.edu/facpub

Part of the Antitrust and Trade Regulation Commons

\section{Recommended Citation}

Thomas, Chantal, "Trade and Development in an Era of Multipolarity and Reterritorialization," 44 Yale Journal of International Law Online 77 (2018)

This Article is brought to you for free and open access by the Faculty Scholarship at Scholarship@Cornell Law: A Digital Repository. It has been accepted for inclusion in Cornell Law Faculty Publications by an authorized administrator of Scholarship@Cornell Law: A Digital Repository. For more information, please contact jmp8@cornell.edu. 


\title{
The Yale Journal of International Law Online
}

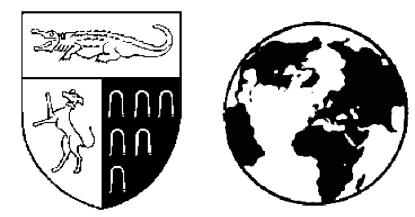

\section{Trade and Development in an Era of Multipolarity and Reterritorialization}

\author{
By Chantal Thomas ${ }^{\dagger}$
}

\section{INTRODUCTION}

This essay will consider two phenomena emergent within international trade law and policy: multipolarity (the emergence of new global powers alongside existing hegemons) and reterritorialization (the rise, sometimes in quite virulent form, of economic nationalism as a basis for asserting State controls over, and barriers to, cross-border trade). These new dynamics present serious challenges and dangers. ${ }^{1}$ This essay will consider whether they might also create opportunities for reshaping the international economic order to be more supportive of the longstanding concerns of developing States. In doing so, the essay will elucidate key aspects of both the global political economy and the international norms and institutions that have helped to shape it.

At several points throughout the history of the current trading system, developing States have struggled to remake the economic order. ${ }^{2}$ Most notably

$\dagger \quad$ Professor of Law, Cornell Law School. I wish to thank participants in the conference, "Trade Law in the Trump Era: A Transatlantic Perspective," held September 2017 at Boston University at the invitation of Professor Daniela Caruso, and the workshop, "Rethinking Trade and Investment Law," held at Harvard Law School in April 2018 with the Institute for Global Law and Policy, for rich discussions pertaining to many of the topics discussed here. Some themes addressed here are also taken up in the Editors' Introduction to GLOBALIZATION REIMAGINED: TOWARDS A PROGRESSIVE AGENDA FOR WORLD TRADE AND InVESTMENT LAW (Alvaro Santos, Chantal Thomas \& David Trubek eds., forthcoming 2019). Errors are of course mine alone.

1. These are ably taken up in several other contributions to this Symposium. See Rachel Brewster, The Trump Administration and the Future of the WTO, 44 YALE J. INT'L L. ONLINE 6 (2019); Timothy Meyer, Trade, Redistribution, and the Imperial Presidency, 44 YALE J. INT'L L. ONLINE 16 (2019); Joel Trachtman, A World Trade Organization for Workers?, 44 YALE J. INT'L L. ONLINE 28 (2019); Gregory Shaffer, A Tragedy in the Making? The Decline of Law and the Return of Power in International Trade Relations, 44 YAle J. INT'L L. ONLINE 37 (2019); Andrew Lang, Protectionism's Many Faces, 44 YALE J. INT'L L. ONLINE 54 (2019).

2. $\quad$ Faizel Ismail, Mainstreaming Development in the World Trade Organization, 39 J. WORLD TRADE 11 (2005). For a history of developing State initiatives on international trade, including events that took place before the era of the New International Economic Order, such as the creation of a "Part IV" on Trade and Development in the GATT and the establishment of the Generalized System of Preferences (GSP) for developing countries, see ROBERT E. HUDEC, DEVELOPING COUNTRIES IN THE GATT LEGAL 
during the era of the General Agreement on Tariffs and Trade (GATT), they sought to do this by crafting an alternate normative framework through the United Nations. This framework was christened by the General Assembly's 1974 resolution calling for "the Establishment of a New International Economic Order [NIEO] based on equity, sovereign equality, interdependence, common interest and cooperation among all States." 3 The NIEO articulated principles of active international redistribution and also supported greater economic sovereignty for developing States seeking to exercise domestic control in an order shaped by the Global North. ${ }^{4}$

Much of this proposed international architecture in support of the strong developmental State ${ }^{5}$ crumbled in the 1980s. Developing States that had supported the NIEO lost much of their global political and economic leverage through a series of internal and external economic crises, paving the way for a revived and strengthened assertion of the imperative to open trade, ${ }^{6}$ as reflected by the GATT's metamorphosis into the World Trade Organization (WTO) in 1995. Only a few short years after the WTO's creation, however, developing States regrouped to bring their concerns back to the negotiating table through the creation in 2001 of the Doha Development Agenda as a frame for further refinement of the trading system. ${ }^{7}$ Yet this effort, too, has fallen far short of its stated objectives. The concomitant rise of new bilateral, regional, and megaregional agreements simultaneously undermined some of the policy gains obtained through the Doha Development talks (such as constraints on patents to ensure access to medicines). ${ }^{8}$ Many of those new agreements contained "WTO-

SYSTEM (1987)

3. G.A. Res. 3201 (S-VI), Declaration on the Establishment of a New International Economic Order (May 1, 1974).

4. See Sundya Pahuja, Decolonizing International LaW 95-96 (2011).

5. "The term developmental state refers to a state that intervenes and guides the direction and pace of economic development." Esteban Pérez Caldentey, The Concept and Evolution of the Developmental State, INT'L J. POL. ECON., Fall 2008, at 27, 28. The term is attributed to Chalmers Johnson's study of Japanese economic growth, CHALMERS JOHNSON, MITI AND THE JAPANESE MIRACLE (1982), and is sometimes used in a geographically specific way to describe the style of State-led economic growth particular to East Asia. See Ziya Öniş, The Logic of the Developmental State, 24 COMP. POL. 109 (1991). Here, I adopt the broader sense of the term, referring generally to the approach to economic development that involves the State directly in a range of economic activity, from planning to financing to production and distribution. See, e.g., Sara Ghebremusse, Conceptualizing the Developmental State in Resource-Rich Sub-Saharan Africa, 8 L. \& DEV. REV. 467 (2015). The developmental State sensibility is informed by a vast array of political, historical, and economic factors from the early period of decolonization forward to the present: in terms of the economic theory underlying it, the mid-twentieth century analyses of "big push" and "balanced growth" industrialization were formative. See Kevin M. Murphy, Andrei Shleifer \& Robert W. Vishny, Industrialization and the Big Push, 97 J. POL. ECON. 1003, 1004 (1989).

6. For general discussions of the relationship between global political economy and reform in domestic and international regulation, see Chantal Thomas, Law and Neoclassical Economic Development in Theory and Practice: Towards an Institutionalist Critique of Institutionalism, 96 CORNELL L. REV. 967 (2011).

7. See World Trade Organization, Ministerial Declaration of 14 November 2001, WTO Doc. WT/MIN(01)/DEC/1, 41 I.L.M. 746 (2002). The Agenda is named for the location of the 2001 WTO Ministerial Conference.

8. See, e.g., Ping Xiong, Patents in TRIPS-Plus Provisions and the Approaches to Interpretation of Free Trade Agreements and TRIPS: Do They Affect Public Health?, 46 J. WORLD TRADE 155 (2012). 
plus" commitments that seemed redistributive to the Global North, as in the case of heightened protections for intellectual property holders and for private investors. ${ }^{9}$

Over the same time period, the global economy saw both an unprecedented expansion of trade and a dramatic increase in global income inequality. The prediction that rich and poor States would "converge" toward an enhanced standard of living turned out to be complicated by fractures opening up within and between States as trade liberalization created economic "winners" and "losers" across the Global North and the Global South. Several of the larger developing States have achieved significant overall gains: in China alone, hundreds of millions of people have emerged from poverty. Yet other States have struggled with continued economic marginalization. For example, many of the less-developed States in sub-Saharan Africa, despite a period of boosted growth associated with a cycle of high commodity prices, did not see substantial gains in poverty reduction. ${ }^{10}$

So what to make of the challenges facing the current trading order and their implications for developing States? The remainder of this essay will elaborate on the two dynamics introduced above in conjunction with these questions.

\section{MULTIPOLARITY}

Since the end of the Cold War, it has been widely recognized that the United States has played the role of global hegemon. It was no coincidence that the emergence of the United States as the sole superpower in the post-Cold War era was accompanied by an increased emphasis on liberal economic policy in the institutions of international economic law. Even before this, however, influence within the trading system was remarkably confined to a small club of economically powerful States. A number of terms that emerged in the lexicon of international trade law and policy evidence this exclusivity. The "Quad," for example, referred to the four entities most often involved in GATT-era dispute settlement over extant rules and most often driving negotiations to establish new ones: Canada, the European Union (formerly the European Economic Community), Japan, and the United States. The "green room"-a process through which States conduct trade talks-evoked a small chamber for the powerful inner circle of Member States who could play an active role in trade rulemaking.

With the emergence of the WTO, the United States achieved many of the objectives it had been pursuing. Most importantly, this included the establishment of an enhanced dispute settlement process with greater institutionalization and enforcement power. ${ }^{11}$ But the imprint of the United

9. While a central benefit of heightened investor protections ostensibly was to promote development in poor countries by encouraging increased foreign direct investment, substantial empirical literature has emerged to question that proposition. See, e.g., THE EFFECT OF TREATIES ON Foreign DiRECT INVESTMENT (Karl P. Sauvant \& Lisa E. Sachs eds., 2009).

10. Kathleen Beegle et al., Poverty in a Rising Africa, World BANK Group (2016), https://openknowledge.worldbank.org/bitstream/handle/10986/22575/9781464807237.pdf.

11. See Understanding on Rules and Procedures Governing the Settlement of Disputes, Apr. 15, 
States was clear in other parts of the new organization as well, from the elaboration of rules on trade remedies ${ }^{12}$ to the incorporation of strong intellectual property protection. ${ }^{13}$

However, in the two decades after the WTO's establishment, the institutional and economic dominance of the United States and the Global North has begun to weaken. ${ }^{14}$ In the global economy, the "BRICS" States-Brazil, Russia, India, China, and South Africa- have emerged as newly salient players. Some of these countries were able to convert economic clout into institutional influence in the WTO. Brazil and China, for example, became adept at advancing their interests through the formal dispute settlement process, scoring a number of important and highly visible victories. India exercised significant influence in the negotiation process, successfully leading the campaign to allow developing States to restrict imports in furtherance of food security objectives. ${ }^{15}$ In doing so, it overcame the objections of the United States and a number of other powerful agriculture-exporting States.

Outside the WTO, the race to create new mega-regional trading blocs became rivalrous with negotiations taking place across different geographical areas. For example, the proposed Trans-Pacific Partnership (TPP) and the Transnational Trade and Investment Partnership (TTIP) each featured the United States as a lead negotiating power. Simultaneously, trade talks conducted by the Association of Southeast Asian Nations (ASEAN) and a proposed Regional Comprehensive Economic Partnership (RCEP) in which China would be the foremost economic power have excluded countries outside Asia. The U.S. withdrawal from the TPP and its repudiation of core commitments within the WTO have further highlighted these alternate spheres of economic influence.

At the level of political economy, the new multipolarity is nowhere more evident than the role China plays in global trade. China produces industrial and manufactured goods and inputs and consumes raw materials and other exports at a level similar to the United States and Europe and much greater than any other market. ${ }^{16}$ Beyond trade, China occupies similar prominence as a source of capital

1994, Marrakesh Agreement Establishing the World Trade Organization, Annex 2, 1869 U.N.T.S. 401.

12. The United States has played an early and consistent role in encouraging the development of multilateral rules on trade remedies. See 2 THE GATT URUGUAY Round: A NEGOTIATING HISTORY (1986-1992) 1405, 1421, 1486, 1519, 1521 (Terence P. Stewart ed., 1993). Relatedly, the United States was at the forefront of the development of multilateral rules on subsidies. See 1 THE GATT URUGUAY Round: A NegOtiating History (1986-1992) 816, 821-25 (Terence P. Stewart ed., 1993).

13. See 2 The GATT URUGUAY Round, supra note 12, at 2253-64.

14. For varied discussions of the significance of this point, see Pasha L. Hsieh, Rethinking the RCEP in the Third Regionalism: Paradigm Shifts in World Trade Law?, in GLOBALIZATION REIMAGINED, supra note 1; Poul F. Kjaer, The End of Trade and Investment Law as We Know It: From Singularity to Pluralism, in Globalization ReIMAgINED, supra note 1; Andrew Lang, Heterodox Market Orders in the Global Trade System, in GlobalizATION ReIMAGINED, supra note 1; Sonia E. Rolland \& David M. Trubek, Embedded Neoliberalism and Its Discontents: The Uncertain Future of Trade and Investment Law, in Globalization Reimagined, supra note 1; Robert Wai, Beyond Normal Trade Law, in GLOBALIZATION REIMAGINED, supra note 1 .

15. Mitsuo Matsushita et al., The World Trade Organization: LaW, Practice, and Policy 298 (3d ed. 2015); see also General Council, Public Stockholding for Food Security Purposes: Decision of 27 November 2014, WTO Doc. WT/L/939 (Nov. 27, 2014).

16. See U.N. Conference On TRAde \& Dev., 2017 Handbook of Statistics, at 23, 90, 94 , 96, U.N. Doc. TD/STAT.42, U.N. Sales No. E.17.II.D.7 (2017). 
through development assistance and investment. ${ }^{17}$ The One Belt, One Road Initiative and the Chiang Mai Initiative provide two of the more visible examples. In sum, the world stage increasingly features not only the United States and its traditional North Atlantic allies, but also leading States from the developing world.

This new multipolarity may create opportunities for developing States, not only to form new economic relationships, but also to establish a new dynamic in international economic law and policy. One of the repeated refrains from development specialists has been to increase "policy space" within international economic institutions - that is, to ensure that developing States have sufficient discretion to depart from a strictly open-market model to cultivate internal economic capacity. ${ }^{18}$ During the Cold War, some developing States were able to cross-leverage the rivalry between the Western and Eastern blocs to generate strategic and material support for their own policies. A world of newfound political and economic rivalry between competing geographical blocs may again create policy space by preventing any one power from fully imposing its own template on weaker States. It is therefore possible that the new multipolar world might open the way for a "Non-Aligned Movement" of the twenty-first century.

Additionally, to the extent that the new powers do have a policy template, it is arguably one that is more supportive of the developmental State than the framework of development policy established in the era of "globalization." The globalization-era framework included wide-ranging substantive directives from conditionalities enforcing neoclassical "structural adjustment" reforms to institutional assessments represented in "good governance" metrics. In contrast, the BRICS States, for example, have established a "BRICS Bank" the stated objectives of which include the provision of alternative means of development assistance that reflects the stated concerns of developing country governments more closely than those of the traditional international financial institutions. ${ }^{19}$ Before Brazil's descent into economic and political instability after 2014, it seemed to exemplify a new standard for socially progressive development strategy ${ }^{20}$ China has demonstrated little interest in the overall policy orientation of its trading partners, opting instead for a largely pragmatic posture. ${ }^{21}$ India,

17. See Ngaire Woods, Whose Aid? Whose Influence? China, Emerging Donors and the Silent Revolution in Development Assistance, 84 INT'L AFF. 1205 (2008).

18. See, e.g., DANI RODRIK, ONE ECONOMICS, MANY Recipes: Globalization, INSTITUTIONS, AND ECONOMIC GROWTH 9 (2007) ("[A] desirable trade regime would be one that provided much greater policy space to developing countries to pursue domestically crafted growth strategies, possibly including unorthodox policies ....").

19. See Sixth BRICS Summit, Fortaleza Declaration (July 15, 2014), http://brics.itamaraty.gov.br/press-releases/214-sixth-brics-summit-fortaleza-declaration.

20. David M. Trubek, Law, State, and the New Developmentalism: An Introduction, in LAW AND the New DeVelopmental State: The BRAZILIan EXPERIENCE IN LATIN AMERICAN CONTEXT 3, 4 (David M. Trubek et al. eds., 2013) (“In this 'new developmental state' approach, the government plays an active role in mobilizing resources, stimulating investment, and promoting innovation. It employs open-economy industrial policy to restructure industry and increase international competitiveness. It uses an active social policy to eliminate poverty, reduce inequality, and stimulate domestic demand. Unlike the developmental state of the 1950 s to the 1980 s, the new developmental state seeks to benefit from participation in the global economy while avoiding the dangers of free-trade fundamentalism.").

21. This phenomenon has been analyzed, for example, in Xiaojun Li, China is Offering "No 
though active in adopting liberalizing reforms in the 1990s, has also more robustly embraced economic nationalism. ${ }^{22}$

Of course, the verdict is still out on whether the new developing powers will demonstrate greater solidarity for smaller economies than have their predecessors in the Global North. China, for example, may be a less ideologically oriented presence than Europe or the United States, ${ }^{23}$ but it may nevertheless pursue its own perceived economic interests. ${ }^{24}$ Relatedly, smaller economies may continue to experience marginalization in the global political economy, whether at the hands of traditional or emerging powers. For example, African governments that expressed concern about being excluded from the Westcentered mega-regionals such as TPP and TTIP are also excluded from the Eastcentered mega-regionals such as RCEP. Moreover, the ability of many of the smaller developing economies to pursue a conventional path of industrialization through manufacturing has been compromised in part by the inability to costcompete with larger developing economies.

There is also the increasing reality that the adjective "developing" no longer describes - if it ever did - a set of relatively typical characteristics across the Global South. Developing States are highly segmented and differentiated. One need only look at the plethora of diverse negotiating blocs within WTO negotiations to realize this. Some groups represent a shared historical background, such as the African, Caribbean, and Pacific (ACP) States, most of which were at one time subjected to European colonialism. But many also occupy a variety of different positions on key law and policy issues in the talks.

On the central issue of agricultural trade policy in the Doha negotiations, for example, developing States that primarily export agricultural products (such as Brazil) have supported increasing market access and liberalizing remaining trade barriers. ${ }^{25}$ Other countries, such as India, which are more focused on their large internal markets, have sought to reinforce their ability to depart from trade disciplines where necessary to protect domestic interests such as food security. ${ }^{26}$ Still others, which depend on imports for food staples, stand to be adversely affected by, for example, India's redirection of staple crops to its own domestic market; these States want talks not only to secure market access for their export

Strings Attached Aid' to Africa. Here's What That Means., WASH. Post: MonKey CAGE (Sept. 27, 2018), https://www.washingtonpost.com/news/monkey-cage/wp/2018/09/27/china-is-offering-no-stringsattached-aid-to-africa-heres-what-that-means.

22. See, e.g., Surajit Mazumdar, Big Business and Economic Nationalism in India, in GlobalizATION AND ECONOMiC NATIONALISM IN ASIA 59 (Anthony P. D'Costa ed., 2012).

23. Perhaps the most classic expression of this is the quote attributed to Deng Xiaoping, who is credited for leading the economic transformation of China: "It doesn't matter if a cat is black or white, so long as it catches mice." GeORge C.S. Lin, Red CAPITALism In South China 46 (1997).

24. See, e.g., Yun Sun, China's Aid to Africa: Monster or Messiah?, BroOKIngS (Feb. 7, 2014), https://www.brookings.edu/opinions/chinas-aid-to-africa-monster-or-messiah (arguing that one objective behind China's investments in Africa is to secure natural resources).

25. See Celso Lafer, Minister of Foreign Relations of Brazil, Statement at the Fourth Session of the Ministerial Conference of the World Trade Organization (Nov. 10, 2001), WTO Doc. WT/MIN(01)/ST/12, at 2 ("The new mandate for agriculture that we establish here must clearly aim at the elimination of distorting trade practices.").

26. SACHIN KUMAR SHARMA, THE WTO AND FoOd SECURITY: IMPLICATIONS FOR DEVELOPING COUNTRIES 10 (2016). 
commodities, which provides needed hard currency, but also to focus on securing development assistance to assuage costs of external food dependence. ${ }^{27}$

In sum, emerging economic and institutional multipolarity creates some benefits but also presents some potential pitfalls for developing States. It may offer more sources for economic growth, and result in a greater degree of domestic policy autonomy. However, at the same time it may further entrench the divergence between the newly industrializing economies and other States in the developing world and may even crowd out those smaller economies from traditional pathways to growth.

\section{RETERRITORIALIZATION}

Alongside the rise of multipolarity in international relations, the current order has pivoted towards economic nationalism as a basis for shaping trade policy. Perhaps most visibly, the United Kingdom has elected to withdraw from the European Union while the Trump administration has rejected or renegotiated its existing trade commitments, such as the TPP, the WTO, and the North American Free Trade Agreement (NAFTA).

Yet these developments in the United Kingdom and the United States are only indicators of what is now a global revival of nationalism. This revival is by no means limited to the North Atlantic countries that were the primary architects of the international economic order. Well before Trump or Brexit, the government of Prime Minister Narendra Modi in India consolidated its power by embracing nationalist economic policies ${ }^{28}$ and Hungarian Prime Minister Viktor Orbán endorsed the construction of an "illiberal state." 29 After the twin shocks to the international status quo of President Trump's election and Brexit in 2016, numerous countries have entrusted conservative nationalists with power: witness the 2018 election of President Jair Bolsonaro in Brazil and significant right-wing parliamentary minorities in Sweden and Germany.

In some ways, the aggressive return of the nation-state, like the rise of multipolarity, may wind up providing additional ballast for the "policy space" so dearly sought by many developing States. After all, in the NIEO days it was the developing world that emphasized robust notions of economic sovereignty. ${ }^{30}$ Now that demands for economic sovereignty are also coming from the Global North, there is arguably less political risk for developing States to pursue policies such as South Africa's 2015 withdrawal from its bilateral investment treaties. This retreat from investor-State dispute settlement (ISDS) stands out much less, and is less likely to give rise to backlash against a perceived repudiation of global

27. For a general overview of diverse concerns of developing countries in the WTO agriculture negotiations, see Understanding the WTO: The Agreements - Agriculture: Fairer Markets for Farmers, WORLD TRADE ORG., https://www.wto.org/english/thewto_e/whatis_e/tif_e/agrm3_e.htm (last visited Dec. 27, 2018).

28. See Ian Hall, Is a 'Modi Doctrine' Emerging in Indian Foreign Policy?, 69 AustL. J. INT'L AFF. 247 (2015).

29. Honor Mahony, Orban Wants to Build "Illiberal State," EUOBSERVER (July 28, 2014), https://euobserver.com/political/125128 (discussing recent public address by Orban).

30. See, e.g., G.A. Res. 3171 (XXVIII), Permanent Sovereignty over Natural Resources (Dec. 17, 1973). 
economic protocols, now that the Global North has also shifted away from ISDS. Other examples of this trend include: the United States-led renegotiation of NAFTA; the replacement of ISDS with an "Investment Court System" in the 2017 Comprehensive Economic and Trade Agreement between Canada and the European Union; and the recently adopted or discussed reforms to the procedural rules of the International Center for the Settlement of Investment Disputes (ICSID) and the UN Commission on International Trade Law (UNCITRAL). ${ }^{31}$

While the formal devolution of power back to States may expand policy space for developing countries, it may also increase their economic precarity. Much of the argument in GATT and WTO law and policy for special and differential treatment (SDT) for developing countries through, for example, the establishment of special access to markets in developed States rested on a principle of international engagement and shared responsibility for global economic equity. ${ }^{32}$ Support for SDT market access and even MFN $^{33}$ market access is now dissipating in the midst of the proliferation of preferential trade agreements. Concurrently, countries like the United States resort to fortifying their trade barriers through a number of legal strategies, ranging from the deployment of national security policy ${ }^{34}$ to the increased use of trade remedies. ${ }^{35}$ In the face of these changes, small economies whose internal capacity continues to be insufficient to drive significant growth will of course be further challenged.

Moreover, the strong developmental State always posed potential concerns for questions of domestic economic distribution and equality. In many instances, classic developmentalist policy arguably legitimated States in sacrificing the health and wellbeing of current populations in the name of future industrialization, through lethal indifference or opposition to labor rights,

31. For further discussion of these developments and related debates, see Sergio Puig \& Gregory Shaffer, Imperfect Alternatives: Institutional Choice and the Reform of Investment Law, 112 AM. J. INT'L L. 361 (2018); Anthea Roberts, Incremental, Systemic, and Paradigmatic Reform of Investor-State Arbitration, 112 AM. J. INT'L L. 410 (2018).

32. See, e.g., T. Ademola Oyejide, Special and Differential Treatment, in Development, TRADE AND THE WTO 504 (Bernard Hoekman, Aaditya Mattoo \& Philip English eds., 2002). This market access system, the GSP, calls for preferential and non-reciprocal access for developing countries. See Decision, Differential and More Favourable Treatment, Reciprocity and Fuller Participation of Developing Countries, 2(a), n. 3, L/4903 (Nov. 28, 1979), GATT BISD (26th Supp.), at 203 (1980).

33. The principle of most-favored nation treatment (MFN) obligates WTO Member States to accord equal trade treatment to each other (unless exceptions, such as those for SDT, apply). General Agreement on Tariffs and Trade, art. I, Oct. 30, 1947, 61 Stat. A-11, 55 U.N.T.S. 194.

34. GATT Article XXI exempts from otherwise applicable trade disciplines certain kinds of measures taken in furtherance of a member State's "essential security interests." Id. art. XXI. The United States has imposed tariffs on steel and aluminum imports, which it claims are necessary to protect national security. Proclamation No. 9,704, 83 Fed. Reg. 11,619 (Mar. 8, 2018); Proclamation No. 9,705, 83 Fed. Reg. 11,625 (Mar. 8, 2018).

35. The rise in the application of antidumping and countervailing duties has been acknowledged, with concern, in communications by the WTO and also, with approval, by the U.S. Department of Commerce within the Trump administration. See, e.g., WTO Members Exchange Views on Rise in AntiDumping Actions (Apr. 27, 2017), WORLD TRADE ORG., https://www.wto.org/english/news_e/ news17 e/anti 10may17 e.htm; Press Release, U.S. Dep't of Commerce (Feb. 13, 2018), https://www.commerce.gov/news/press-releases/2018/02/us-department-commerce-initiates-

antidumping-duty-and-countervailing ("With an 81 percent increase in trade cases initiated since President Trump took office, this Administration has made it clear that we will vigorously administer antidumping and countervailing duty laws,' said Secretary [of Commerce Wilbur] Ross."). 
environmental fallout, and other forms of social policy. ${ }^{36}$ The "strong State" posture may obscure the ability of alternate internal voices to organize for improved conditions for themselves by appealing to their governments' international commitments. ${ }^{37}$

\section{CONCLUSION}

Such questions of responsibility for global justice and equality have been fraught through the entire lifespan of international economic institutions, as those institutions have permutated through one or another set of legal and policy orientations. The world trading order is now confronting perhaps the clearest existential crisis it has faced since the establishment of the GATT just after World War II. That the threat to the GATT's successor institution, the WTO, stems most directly from the actions of the United States under the Trump administration represents a most surprising turn of events, since the United States was far and away the most influential in its creation. A central function of the trading system, established as it was in a world newly emerging from global war, has been not only to create economic prosperity, but also to help secure international peace and stability by reducing the ability of States to channel political hostilities through trade policy. Consequently, the full implications of this moment of uncertainty for the multilateral trade regime remain unknown. It remains to be seen whether, and in what form, legal and institutional obligations towards international cooperation to achieve global equity, in the form of economic development, will survive this brave new world order.

36. A globally reported example of lethal labor conditions was the 2013 building collapse in Rana Plaza, a garment manufacturing hub outside Dhaka, Bangladesh, that killed 1,134 workers. For a discussion of the respective roles of the Bangladeshi government, multinational corporations, and global consumer demand, see Jason Burke, Rana Plaza: One Year on From the Bangladesh Factory Disaster, THE GUARDIAN (Apr. 19, 2014), https://www.theguardian.com/world/2014/apr/19/rana-plazabangladesh-one-year-on.

37. Such appeals are by no means always successful. For example, a high-profile joint effort of U.S. and Guatemalan labor movements to enforce labor standards in Guatemala through the Labor Chapter of the U.S. trade agreement with Central America (CAFTA-DR) ultimately failed. For a highly critical discussion, see Ciaran Cross, Failure by Design: Did the U.S. Choose to Lose the Guatemala Labour Dispute?, 24 INT'L UNION RTS., no. 3, 2017, at 23. 